11. Oeming AF (1955) A preliminary study of the Great Gray Owl (Scotiaptix nebulosa nebulosa) (Forster) in Alberta with observations on some other species of owls. M.Sc. thesis, University of Alberta, Edmonton, AB.

12. Law C (1960) The Great Gray Owl of the woodlands. Blue Jay 18:14-16.

13. Nero RW (1969) The status of the Great Gray Owl in Manitoba, with special reference to the 1968-69 influx. Blue Jay 27:191-209.

14. Altmann SA (1956) Avian mobbing behavior and predator recognition. Condor 58:241-249.

15. Bull EL, Henjum MG (1990) Ecology of the Great Gray Owl. United States Department of Agriculture, Forest Service, General Technical Report, PNW-GTR-265.

16. Broun M (1947) Golden Eagle captures Red-shouldered Hawk. Auk 64:317-318.
17. Collins CT (1962) Red-tailed Hawk attacks Long-eared Owl. Wilson Bulletin 74:89.

18. Weigand JP (1967) Ferruginous Hawk attacks Great Horned Owl. Auk 84:433.

19. Clark RJ (1971) Red-tailed Hawk attempts piracy of Sparrow Hawk? Kingbird 21:10.

20. Todd DM (1980) Golden Eagle killing Buzzard. British Birds 73:536-537.

21. Nero RW (1994) Short-tailed shrew apparently cause of mortality of Eastern Screech-Owl. Blue Jay 52:176-178.

22. Gibson MJ, Gibson DC, Bardelmeier DG (1998) Prey conquers predator: a case study. Journal of Wildlife Rehabilitation 21:19-21.

23. McNicholl MK (1973) Habituation of aggressive response to avian predators by terns. Auk 90:902-904.

\title{
MAMMALS
}

\section{WEASELS; NOT ALWAYS PUSHOVER PREY FOR RAPTORS}

WILLIAM J. WALLEY, 222 Bossons Ave., Dauphin, Manitoba, R7N OR2

Known avian predators of weasels (Mustela sp.) include: northern goshawk, red-tailed and rough-legged hawks; northern barred, great horned and snowy owls. ${ }^{1,2,3,4,5,6,7,8,9}$ Banfield excluded mustelids as prey of raptors. 10 On occasion weasel remains link these mustelids to unusual predators such as the discovery at Hamilton Bay, Ontario where a bald eagle (Haliaeetus leucocephalus) that had been shot, had a "bleached skull of a weasel hanging firmly fastened by the teeth into the skin of its throat, a gruesome relic of a former desperate struggle" reported by Thomas Mcllwraith to A.C. Bent. ${ }^{1}$ In 1980 the author discovered the skull of a shorttailed weasel (Mustela erminea) in the cast pellet of a short-eared owl (Asio flammeus) near Dauphin, Manitoba, the only reported such record for this owl species for the entire holarctic. ${ }^{11}$ No 
records consulted reported the northern harrier (Circus cyaneus) as a predator of weasels but on 30 April, 1995, a large short-tailed weasel was seen running across a snow drift toward a thicket of willows behind the beach ridge at Stony Point on the west shore of Dauphin Lake, the outcome of which was undetermined.

Fearless, the weasel backs up its feisty nature with sharp teeth and claws making a raptor's intent of having a meal of weasel far from a certainty - not to dismiss the fact that the weasel may, on occasion, be the aggressor as noted by Criddle and Criddle. ${ }^{12}$ J.K. Terres noted a red-tailed hawk (Buteo jamaicensis) being bitten and killed by a weasel that had been carried aloft by the hawk. ${ }^{2}$

In western Manitoba various verbal accounts have been described to the author where weasels have successfully escaped from raptorial birds in flight. Over a hay field just south of Riding Mountain National Park (RMNP) a farmer noted a red-tailed hawk experiencing flight difficulties. Suddenly the hawk plunged to the earth whereupon impact a weasel ran off. The hawk was quickly attended to and was found to have sustained several bites but took wing shortly (D. Juce, Pers. Comm.). One summer in the Birdtail Valley near Birtle, another red-tailed hawk didn't fare as well. Acting unusual above its observer E.C. Walley (Pers. Comm.) it fell to the earth, again with a weasel running away. The bird soon hemorrhaged to death from a laceration of a large blood vessel in its neck.

J.D. Robertson (Pers Comm.) former supervisor of Conservation Officers in northern Manitoba related a sighting made by one of his C.O.s in the 1940s: one winter morning a Snowy Owl was seen in flight in the delta of the Saskatchewan River east of The Pas. Suddenly and to the utter amazement of the officer, the owl began to have difficulty flying and soon fell to the snow-covered ice, whereupon a short-tailed weasel loped off. Examination of the owl showed that a large blood vessel under one of its wings had been severed.

This report describes a weasel-raptor struggle with a different twist. It occurred under overcast skies at 8:30 hours on 26 November, 2005 some $12 \mathrm{~km}$ WNW of the City of Dauphin, Manitoba north of RMNP. That morning four of us were proceeding by vehicle along a frozen dirt road adjacent an alfalfa field in farmland/aspen grove habitat when someone yelled: " a hawk with a rabbit's leg!" Looking from the far side of the vehicle I saw a roughlegged hawk (Lagopus lagopus) with an ermine (short-tailed weasel) in its talons as it lifted above the field about $20 \mathrm{~m} \mathrm{~S}$ of us. The weasel which had been grasped in the shoulder area, hung limp and appeared to be decapitated although no blood could be seen. Within two or three seconds, the hawk, with wings beating hard, dropped the seemingly dead ermine which fell $1.5 \mathrm{~m}$ to the ground. Instantly upon contact with the earth the weasel "sprang to life" and began chasing the hawk leaping upward $50-60 \mathrm{~cm}$ at it at least twice before the buteo was well out of reach flying $100 \mathrm{~m}$ to a bale where it alighted apparently uninjured. The field which was a mosaic of $8-10 \mathrm{~cm}$ deep snow and mowed alfalfa patches, was immediately and intensively searched, not only for the weasel itself, but for drops of blood that would have indicated injury to it. However neither was found.

It cannot be assumed that the weasel escaped on its own. One early summer morning while driving along a highway, a red-tailed hawk suddenly flushed from the ditch with prey in its talons. As my vehicle came abreast of it the hawk dropped a fairly well grown young American coot (Fulica americana) then frantically beat its wings to withdraw from 
the site. Clearly the prey was jettisoned to facilitate "escape," but in this hawk/ weasel scenario did the weasel, with a well placed bite, induce the hawk to release it or was the weasel released by the hawk to hasten its departure from the scene? Probably the latter - the limp appearance of the "prey" in the talons of the raptor suggested death rather than aggression, but: if the ermine was the hunted, why did it appear to quickly become the hunter chasing and leaping up at the hawk? It seemed that the predator/prey roles had been dramatically reversed!

Naturalist Dick Decker ${ }^{13}$ described a long-tailed weasel (Mustela frenata), apparently apprehensive of Decker's presence nearby, repeatedly race outward two or three metres from a burrow, then leaping into the air $70-80 \mathrm{~cm}$ as it turned and returned to the hole. Decker interpreted this behavior as a defensive/ aggressive tactic to dissuadea potential attack by a hawk or owl though there was no known predator about. If Decker is correct, the Dauphin observation of the weasel's actions after release (escape?) were not to exact revenge on the hawk but were a defensive maneuver to discourage a second attack. Could this behavior described by Decker for $M$. frenata now be extended to $M$. erminea pending additional documentation? On the other hand, and much more remotely, had the weasel been the aggressor that had had the tables turned on it, only to be fortuitously spared by our party's arrival?

1. Bent, AC (1961) Life histories of North American birds of prey. Part 1. Dover Publications, New York.

2. Terres, JK (1980) The Audubon Society encyclopedia of North American birds. Alfred A. Knopf, New York.
3. Craighead, FC, Craighead, JJ (1956) Hawks, owls and wildlife. Stackpole Co., Harrisburg, PA.

4. Bent, AC (1961) Life histories of North American birds of prey. Part 2. Dover Publications, New York.

5. Fisher AK (1893) The hawks and owls of the United States in their relation to agriculture. United States Agriculture, Division Ornithology and Mammalogy. Bulletin 3. In: Bent, AC (1961) Life histories of North American birds of prey Part 1. Dover Publications, New York.

6. Schowalter, DB, Engley, L Digby, R (2002) Records of Alberta small mammals through analyses of great horned owl pellets. Blue Jay 60: 153 - 167.

7. Gerard, M, K, Zazeleschuk, D (2009) A sample of prey remains found in great horned owl nests in Saskatchewan in 2008. Blue Jay 67: 71 - 76.

8. Boxall, PC (1979) Interaction between a long-tailed weasel and a snowy owl. Canadian Field-Naturalist 93: 67 - 68.

9. Gross, AO (1944) Food of the Snowy owl. Auk 61: 1 - 18.

10. Banfield, AWF (1974) The mammals of Canada. National Museums of Canada, Ottawa.

11. Walley, WJ (1982) Weasel skull in short-eared owl (Asio flammeus) pellet. Canadian Field-Naturalist. 96: 81.

12. Criddle N, Criddle S (1925) The weasels of southern Manitoba. Canadian Field-Naturalist. 39: 142 - 148.

13. Decker, D (2002) Defensive behaviors of long-tailed weasels. Blue Jay 60: 115 $-116$. 